\title{
Strīvilāsa - An Ayurvedic Manuscript on Cosmetic Procedures of Females, Aphrodisiacs, Diseases and Medicines
}

\author{
Goli Penchala Prasad*, P Swathi***, K Bharathi*, G Babu*, \\ N Srikanth** and KS Dhiman**
}

(Received 13 March 2017; revised 07 July 2017)

\begin{abstract}
Strīvilāsa, an unexpolred Āyurvedic manuscript in Devanagari script deals with cosmetic procedures of female comfort. It is a text with major focus on female health, pleasures and comforts to make her beautiful, disease free and full of vitality. The book containing seven chapters describes various treatments for the diseases of female, aphrodisiac medicines, various vïryasthambhana leppa (anointments) and internal medications for male. Yōnīsamkīcanayōga (formulations for vaginal narrowing), Stana kațin̄karana yōga (drugs used to make breast firm and beautiful), various beautifying drugs like depilators and hair enhancers, complexion promoting drugs, anti-lice drugs, drugs to cure diseases like alopecia, pimples, foul smell of body are described. It also describes the treatment of various gynecological disorders and infertility; preparations for easy labor and antenatal care. Though some researchers tried to review the contents of the book, so far entire content of the manuscript is not translated in to English and also not published. Most probably this is the first independent work on gynaecology. It is unique and may give various leads for scientific fraternity involved in Āyurvedic obstetrics and gynaecology.
\end{abstract}

Key words: Aphrodisiac, Āyurveda, Infertility, Sterility, Strīvilāsa, Vīryasthambhana

\section{INTRODUCTION}

Strīvilāsa is an Ayurvedic manuscript written in Sanskrit language in Devanagari script. It was procured from Government Ayurvedic College, Gwalior by National Institute of Indian Medical Heritage, Hyderabad, under the project "Collection and Digitization of Medical Manuscripts from South India Maharashtra and Madhya Pradesh (CDMM)". It is a paper manuscript containing 42 folios ( 84 pages) and each folio measuring $24 \mathrm{~cm}$ long and $16 \mathrm{~cm}$ wide. Approximately each paper contains 11 lines with 34 letters in each line. Granthamana (total letters of the manuscript) is approximately 31416 $(34 \times 22 \times 42)$. As per the description given in the text, it appears that the name of the author is Dēvēśvara Upādhyāya, belongs to Gaudajāti; son of Murāri and scribe is Parāśarajaigōpāla. Subject matter is presented in seven chapters entitled as Taranga. Time of the completion of manuscript is described as Sunday, dark lunar fortnight of month of Phalguna, samvat 1886/ saka 1751. Title of the manuscript itself denotes the subject and theme of the book. It is an exclusive book with a mission to provide complete comfort to woman. As per Janet Chawla, it is the first independent work on prasūtitantra and strīrōga (obstetrics and gynaecology) (Chawla, 2006, pp.145-46). Krishnamachariar considered this as a main text on Kämaśāstra (art of love) (Krishnamachariar,

\footnotetext{
* Regional Ayurveda Research Institute for Skin Disorders (RARISD), Vijayawada

**Central Council for Research in Ayurvedic Sciences, New Delhi

***Sampurnanand Sanskrit University, Varanasi

Corresponding author: Goli Penchala Prasad, RARISD, New Rajiv Nagar, Payakapuram, Vijayawada, 520015, Andhra Pradesh, Email: drprasadgoli@yahoo.com
} 
1989, pp.896). In the initial slokka the author conveys that he had read many ancient classical Āyurvedic texts like Caraka, Suśruta, Vāgbhața, $\bar{A}$ trēya, Vamigasēna etc. samihitā and he had followed those ancient scholars. The subject of the text deals with topics related to art of love, obstetrics and gynaecology. Aphrodisiacs medicines, formulations for delaying ejaculation, drugs for vaginal narrowing, competent medicines to make breast firm and beautiful, medicines for female orgasm, depilators, deodorants, hair enhancers are some of the examples for enhancing art of love. Subject matter of Gynaecology is dealt under the topics like management of menarche, menorrhagia, various types of infertility and their treatment. Obstetrics are dealt under the headings - failure of lactation, antenatal care and treatment for antenatal ailments and management of obstructed labour. By looking into the subject matter it appears that it is the first text exclusively dedicated for both art of love and obstetrics and gynaecology. Probably it is the first text in classical and non classical Āyurvedic texts entitled on woman. This text has some unique additions to available published Āyurvedic texts.

\section{Content and Methodology of the Text}

Digitized copy of the original Strivilāsa manuscript is the basis for the present work. Sanskrit ślokas are studied to understand the content of each chapter. Unique topics, treatments and formulations are given due importance and tried to emphasize further. Ingredients of many formulations are studied and presented in this work with suitable botanical / English names. As the title conveys it is a text with the aim to provide the female with all sorts of pleasures and comforts by making her beautiful, disease free and even making her male partner with full of manly vigour and vitality. Total Manuscript is thoroughly studied and content of the each chapter (taranga) is recorded and the important things are presented to highlight the content of the text to inculcate the joy and beauty of the text to the reader and to highlight the leads to the researchers and scholars for further study and research.

\section{Aphrodisiac Medicines}

Aphrodisiac medicines are indicated to enhance manly vigour, semen virility, renewed energy in sexual act and to get good progeny. Among the herbo-mineral aphrodisiac medicines paincaśaranamarasa is the one that contains mercury, sulphur, juice of root of śâlmalī (Salmalia malabarica SCHOTT \& ENDL.) as the main ingredients; madanarasa is the other drug that possesses mercury, kākasavalkatoya (opiumlatex of fruit of Papaver somniferum L.), mica, sulphur, bitumen, agaru (Aquilaria agallocha $\mathrm{ROXB}$.), cloves etc.; Madanakāmadēvarasa contains mercury, sulphur, copper, ghee, juice of roots of śâlmalī (Salmalia malabarica SCHOTT \& ENDL.), kākōli (Roscoea procera WALL.), vidāri (Pueraria tuberosa (ROXB.EX.WILLD.), śatāvari (Asparagus racemosus WILLD.), aśvagandha (Withania somnifera DUNAL); fruit of ämalaki (Emblica officinalis GAERTN.) etc. as the main ingredients.

Among the herbal preparations Māsamōdaka is a black gram recipe fried in cow's ghee impregnated in cow's milk and juice of bulb of vidārī (Pueraria tuberosa (ROXB. EX. WILLD.) DC.). Māsavațaka is also a black gram recipe (vada) prepared from the powder of dehusked black gram, coconut water, cow's milk, mōcarasa (Salmalia malabarica SCHOTT \& ENDL.) and śatāvarī (Asparagus racemosus WILLD.). Apart from herbo-mineral and herbal preparations traditional dishes are also indicated for aphrodisiac purposes viz. puri (a light, round, unleavened wheat bread of India, usually deepfried) prepared from the mixture of powders of black gram, rice, wheat, barley, long pepper along with cow milk and sugar; gajjaravidhi, a recipe of carrot prepared from carrot, goat's milk, ghee etc.; 
palāndu prayōga, a recipe of onion and garlic along with ghee etc.

\section{VīrYASTHAMBHANA AND Lingamú́ślít Karana Formulations}

Vìryasthambhana means holding seminal discharge till desired time/delaying ejaculation and preventing premature ejaculation and lingamuśalikkarana is to make penis hard like wooden pestle. Many vīryasthambhana guț (tablets) are mentioned in this text. Kāsmaryā $d i$ guti is a tablet prepared from kāsmarī (Gmelina arborea L.), tankana (borax), mace, akalllaka (Anacyclus pyrethrum DC.), himgula (cinnabar), bōla (resin of Commiphora myrrha ENGL.), nutmeg, dry ginger, cloves, opium etc. triturated in juice of betel leaf. Sthambhanasimha guti is a tablet prepared from nutmeg, seeds of datura (Datura metel L.), mace, akalllaka (Anacyclus pyrethrum DC.), vatsanābha (Aconitum ferox WALL. EX SERINGE), opium etc. triturated in juice of betel leaf. Turaingī guti is a tablet prepared from $m \bar{e} t h \bar{\imath}$ (fenugreek seeds), mōcarasa (Salmalia malabarica SCHOTT \& ENDL.), javāni (Carum copticum BENTH.), musalī (Curculigo orchioides GAERTN.), dīpya (Carum roxburghianum KURZ.), tṛtī (cardamom), akallaka (Anacyclus pyrethrum DC.), mace, nutmeg etc. Apart from the above, tablets like Tējanīsthambhana gutikā; Viśvādi sthambhana guțikā, Vìryasthambhana guțikā; Ahiphēna guțikā; Jātīphalādiguțikā, Kāmadēvaminutikā etc. are also explained for delaying ejaculation and preventing premature ejaculation.

Many external anointments (lêpa) for lingamuśalikkarana are explained in this text. One recipe for Kațibaindhēsthambhana i.e delaying ejaculation is mentioned to obtain by knotting of the medicated thread on lumbar region; one drink for delaying ejaculation and some chewing recipes for delaying ejaculation are also narrated. For the same effect author described various leppa, which are to be applied on umbilicus, feet, nails etc. In these recipes, catakānda (eggs of sparrow), fish, teeth of pig, gumja $\bar{a}$ bija (seeds of Abrus precatorius L.), samudraphēna, nāgakēsara, dattūrabīja (seeds of Datura metel L.), kapikacchūbīja (seeds of Mucuna pruriens (L.; DC.), bitter guard, nutmeg, mace, marking nut, camphor, mercury etc. drugs are used. Dippayōga is a special method to elevate the mood of the male partner in the room that contains a lamp ignited with fibers of root of svêtârka (Calotropis procera R.BR.) and fat of pig for delaying ejaculation.

\section{Beautification of Woman and Sexual Vigour}

Physical beautification of woman with yōnisankōcana (narrowing of lax vaginal canal or making the vagina firm), yōnidurgandhaharana (vaginal deodorants), apānavāyu durgandhaharaṇa (alleviating foul smell due to flatulence), yōni lōmaharạ̣a (vaginal depilating) and stana katinīkarana (for shaping or hardening the breast) are explained. Female sexual enjoyment is explained under the heading strīdrāvaṇām (female orgasm).

\subsection{Yōnisankōcana (Narrowing of lax vaginal canal or making the vagina firm)}

These recipes are mainly indicated for middle aged woman and to postnatal woman. Drugs like dugdhikā (Euphorbia hirta L.), stamen of lotus, dèvadru (Cedrus deodara (ROXB.) LOUD.,) dhātakī puspa (flowers of Woodfordia fruticosa (L.; KURZ), triphalā (three myrobalans), jambu (Syzygium cumini (L.; Skeels), madhuka (Madhuca indica GMEL.), ikșvākubija (seeds of Lagenaria siceraria (MOLINA; STANDLEY), katutumbībijja (seeds of bitter variety of Lagenaria siceraria (MOLINA; STANDLEY), lödhra (Symplocos racemosa ROXB.), root of bitter guard, madayantikā (Lawsonia inermis L.), aśvagandhā (Withania somnifera DUNAL), mōcarasa (Salmalia malabarica SCHOTT \& ENDL.), niśáyugma (haridrā-turmeric- Curcuma 
longa L. and dāruharidrā-Berberis aristata DC.), amalaka valkala (fruit rind of Emblica officinalis GAERTN.), khadirā (Acacia catechu (L.F.; WILLD.), etc. are suggested to use in the form of tablets, external ointments (lēpa), douching/ washing decoctions (praksālaṇa), massage oils etc.

\subsection{Yōnidurgandhaharaṇa (Vaginal Deodorants)}

These recipes are indicated for deodorizing the vaginal foul smell. Camphor, kastūri (musk), pañcapallava (aggregate of 5 sprigs or shoots of the mango, Syzygium cumini (L.) (SKEELS), Feronia elephantum (CORREA), Citrus medica L., and Aegle marmelos (L.; CORREA EX. SCHULTZ), niśā (turmeric), jasmine flowers, nimbha (neem), Terminalia arjuna (ROXB.) WIGHT \& ARN etc. drugs are used for preparation of decoctions for washing, oils for massage and powders/smoke to incense the vagina.

\subsection{Apānavāyu durgandhaharaṇa yōga} (Formulation that alleviates foul smell due to flatulence): Eating of rock salt along with mātulumga (Citrus medica L.) alleviates foul smell due to flatulence.

\subsection{Yōni lōmaharaṇa (Vaginal depilating)}

Powder of snake skin (cast off skin) triturated in mustard oil; bhasma of palāśa (Butea monosperma (LAM. TAUB), bhasma of tāla (yellow orpiment), raimbhā (bulb of banana), tankana (borax) etc. are mentioned for the usage in the preparation of anointments and oils for $y \bar{o} n i$ lōmaharana (vaginal depilating). Kșārataila (alkaline oils) prepared from sukti (oyster shell), śambhūka (snail shell), śamkha (conch shell), mauktika (pearl) etc. are also used as depilators.

\subsection{Stana katinīkarana (Shaping or hardening the breast)}

Many recipes are mentioned for stana katinīkaraṇa. Mātanga (bhangā ?), kuṣțā
(Saussurea lappa C.B.CL.), aśvagandhā (Withania somnifera Dunal), triphala (three myrobalans), pathyā (Terminalia chebula RETZ. \& WILLD.), camphor, agaru (Aquilaria agallocha ROXB.), pulp of pomegranate, mustard, sriparṇi (Gmelina arborea L.), bhasma of cast skin of snake etc. drugs are the ingredients used in external pastes, massage oils and internal decoctions. Medicated oil prepared by cooking tila taila (sesame oil), cow's milk, latex of arka (Calotropis gigantea (L.; R.BR.), paste of bala (root of Sida cordifolia L.), mālatī (jasmine), vyōca (three myrobalans), lajjālu (Mimosa pudica L.), niśādvaya (haridrā- turmeric and dāruharidrāBerberis aristata DC.), is indicated as errhine for proper shaping of the breast with firm musculature.

\subsection{Strīdrāvanām (Female orgasm)}

Strīdrāvanām is a novel term used to denote female orgasm (the moment of most intense pleasure in sexual intercourse). Many anointments/ pastes are mentioned to apply over penis during copulation to get orgasm. Ripe tamarind fruit, honey, tankana (borax), camphor, leaf of agastya (Sesbania grandiflora (L.; POIRET), lödhra (Symplocos racemosa ROXB.), black pepper, long pepper, root of büjapūra (Citrus medica L.), old jaggery, seeds of dhatura (Datura metel L.), root of arka (Calotropis gigantea (L.; R.BR.), flowers of red variety karavīra (Nerium odorum SOLANED) etc. are the some of the ingredients used for the preparation of pastes and oils for the purpose of strīdrāvanām (female orgasm).

\section{Sterility Inducing}

Under the heading of khäm recipes those make the male temporarily or permanently samda (sterile) are discussed. Turmeric, camphor, burnt leech etc., are used to make sterile and gōksura (Tribulus terrestris L.), tila (sesame seeds), goat's milk, flowers of dhatura (Dhatura metel L.) etc. are used to regain potency and pacify sterility. 


\section{Cosmetics}

Many cosmetic medicaments and procedures are discussed in this text. Śarīra durgandhaharaña yogga (deodorant recipes), kéśavardhana and ranjana (hair enhancers/ vitalizers and hair dyes), kéśaśuklīkarana (turning black hair to white), medicines to relieve alopecia, yūka nivārana yōga (recipes to kill the lice), facepacks to control pimples, mukhavāsakarana (mouth fresheners) etc. are some examples.

\section{1 Śarīra durgandhaharaṇa yōga (Deodorant recipes)}

Pastes and powders prepared from harìtaki (Terminalia chebula RETZ. \& WILLD.), lōdhra (Symplocos racemosa ROXB.), dadimavalkala (fruit rind of pomegranate), candana (sandal wood), musta (Cyperus rotundus L.), root of śriphala (fruit of Aegle marmelos (L.; CORREA EX. SCHULTZ), fruit of tamarind, agaru (Aquilaria agallocha ROXB.), candana (sandal wood) etc. are used in these recipes.

\subsection{Kēśavardhana and ranjana (Hair enhancers/ vitalizers and hair dyes)}

Cosmetic procedures like Kéśavardhana and ranjana (hair enhancers/ vitalizers and hair dyes) are given high importance and stressed the importance of hair dying by quoting that "ornaments of head on white hair don't look good". External application of medicated ghee for 7 days that is prepared from sesame flowers, gōkșura (Tribulus terrestris L.), cow's ghee provides long and healthy hair. Oil prepared from madantikā (Lawsonia inermis L.), sācara (Barleria prionitis L.) and sesame oil also vitalizes the hair. Nīli (Indigofera tinctoria L.), saindhava (rock salt), pippali (long pepper), śatāvarī (Asparagus racemosus WILLD.), black sesamum, gōrōcana (purified gall of cattle), karkaśa (svalpakarkōma- small variety of momordica dioica ROXB. EX WILLD (Sharma, 1997, pp. 3435), viḍanga (Embelia ribes BURM.F.), gandhōpala (priyangu- Callicarpa macrophylla,
(Sharma,1997, pp. 60, 120), gōmūtra (cow's urine), katutaila (mustard oil), gumjā (Abrus precatorius L.), kètakīkanda (bulb of Pandanus odoratissimus L.F.), triphalā (three myrobalans), picumanda (seeds of neem), kāśmarya (Gmelina arborea L.), lajjālu bīja (seeds of Mimosa pudica L.), mahākālasya bīja (viśâla bīja -seeds of Trichosanthes palmata ROXB. (Sharma,1995, pp.63), etc. drugs are used in the preparation of oils, pastes, decoctions; nasal drops used for hair growth and many temporary hair dyes.

\subsection{Yūkā nivārana yōga (Recipes to kill the lice)}

It is prepared by triturating mercury in betel leaf juice.

\subsection{Kēśaśuklīkaraṇa (Turning black hair to white)}

It is attained by the medicated oil extracted from the black sesame seeds triturated in latex of vajrī (snuhī-Euphorbia neriifolia L.).

\subsection{Indralupta (alopecia)}

It is treated with external application of the paste of fruit of gunjā (Abrus precatorius L.) and honey and external application of ash of ivory.

\subsection{Mukha kantaka (pimples)}

External paste prepared from sindh $\bar{u}$ (Vitex trifolia L. F.), siddhārthaka (yellow mustard), vaca (Acorus calamus L.), śālmalìkamtaka (thorns of Salmalia malabarica SCHOTT \& ENDL.), dhānyaka (coriander), nis̄ādvaya (haridrāturmeric and dāruharidrā-Berberis aristata DC.) etc. are used to relieve mukha kantaka (pimples).

\subsection{Facepacks}

Mukha chāyā haraña (alleviate blackness in face) is achieved by mukha lèpana yogga (facial packs) etc. Kumkuma (saffron), candana (sandal wood), patra (Cinnamomum tamala NEES \& EBERM.), uśîra (Vetiveria zizanioides (L.; NASH), gōrōcana (gall of cattle), haridrādvaya (haridrā- turmeric and dāruharidrā- 
Berberis aristata DC.), manjișthā (Rubia cordifolia L.), yaśti (Glycyrrhiza glabra L.), śārivā (Hemidesmus indicus (L.) SCHULT.), lödhra (Symplocos racemosa ROXB.), pattanga (Caesalpinia sappan L.), kușthā (Saussurea lappa C.B.CL.), gairika (red ochre), priyamgu (Callicarpa macrophylla VAHL), kālīya (pītacandana- Coscinium fenestratum (GAERTN.) COLEB (Sharma, 1997, pp. 41) etc. are used as ingredients of face pack.

\subsection{Mukhavāsakaraṇa (Mouth fresheners)}

Seed kernel of mango and jambu (Syzygium cumini (L.) SKEELS); èlā (cardamom), nakha (shell of sea animal that is in the shape of nail (Sharma, 1995, pp.144, jātī (jasmine), kēsara (Mesua ferrea L.), kumkuma (saffron) etc. are used as mukhavāsakarana (mouth fresheners).

\section{Female Sterility}

This text describes nine types of vandhya (barren/sterile female) like yōnicalanaim, māmsavrddhika, vāyugranthi, krmija, śîtāmga, pittaprakōpa, śākinīdossaja, dēvadōsaja and kāmanaindōsaja. Characteristic features of nine types of vandhya and their, treatments are explained. Unlike other texts here characteristic feature of these barren woman during or after coitus are explained. For example, yōnicalanam after coitus suffers from headache, māmsavrddhika from backache, vāyugranthi from abdominal pain, etc. Along with above types, vandhyatva (female infertility) due to sannipātadōṣa, raktadōsa, navagrahadōṣa, abhighātadōṣa, abhișaimgadōṣa, bharttavīryadossa, etc. along with their characteristic features, treatments are also described.

\section{VANDhȳ Cikitsā (TREATMENT OF infertility) and Antenatal Care}

Vandhya cikitsa (treatment of infertility) and antenatal care are dealt in detail in this text.
Vandhyā strī snāna vidhi (special bath for infertile woman) has been given special concern. Before bath administering the mixture of powders of nalinī (lotus), kuștha (Saussurea lappa C.B.CL.), candana (sandal wood), èranda (Ricinus communis L.), tagara (Valeriana wallichii DC.), aśvagamdha (Withania somnifera DUNAL), usíra (Vetiveria zizanioides (L.; NASH) etc., udvartana (medicated coarse powders rubbing) and after bath prayers are mentioned. Various types of prayers and baths for infertile woman, prayers with various types of waters and seven types of fruits like nārikēla (coconut), nārañga (orange), dādima (pomegranate), utati (Echinops echinatus ROXB.?), pumga (Areca catechu L.?), bījapūraka (Citrus medica L.) and madana (Randia dumetorum LAM.); chanting (prayers) of seven herbs like vrddhāvari (Asparagus racemosus WILLD.?), rāsnā (Pluchea lanceolata OLIVER \& HIERN.), èlā (cardamom), vacā (Acorus calamus L.), dhānyā (coriander), niśa (turmeric) and bahuphalī (Phyllanthus emblica L./ jujube ?) are explained. Chanting of various deities and after chanting, medication procedures for sterile woman are explained. Chanting mantras during the collection of the herb, during the intake of medicines etc. are also explained.

Diagnosis of gender of the foetus while observing characteristic features of pregnant, antenatal care was mentioned. Ingredients and preparation of various medicines used in the treatment of sterile woman to make her conceive the child are explained. Putrapradanamarasa, Jayasumdararasa, Ratnabhāgōttararasa, Cakrībaddharasa, Putravardhamānarasa, Abhrakasūtarasa, Phalaghrta, Putrataila, Saṁtānārthaguțika, Samitānōpariguṭi etc are some important formulations indicated in this text for sterile woman. Samitānaupacāra (care and medicaments for new born child); vaìdhyāstrīsamiānaupacāra (care and medicaments for new born child of woman who was sterile for long period) are unique to this text. 
This text covers topics like kākavandhy $\bar{a}$ (one child infertility), mrtavatsā (female with history of stillbirth), garbhasrāva (abortion of first or second trimester), sukhaprasava (eutocia), mū dhagarbha (obstructed labour), nālappravrtti (separation of umbilical card), naștadugdha (lactation failure), yonipradara (leucorrhoea and menorrhagia) and vandhya (barren woman).

\subsection{Käkavandhya cikitsa $\bar{a}$ (Treatment of one child infertility/ secondary infertility)}

Under kākavandhyā cikitsā (treatment of one child infertility/ secondary infertility) along with sacred ceremonies many recipes are mentioned. Viṣnukrānta (Evolvulus alsinoides L.), aśvagandhā (Withania somnifera DUNAL), kāravallìmūlakamda (bulb of Momordica charantia L.) etc. drugs are used in these recipes.

\subsection{Mrtavatsācikitsa (Treatment for female with history of stillbirth)}

Along with sacred ceremonies recipes like different types of Sañtānārdha guțika, Santānōpaguțī, Samitānōpacāra cūrṇa etc. are mentioned. Pārśsvapippalībīja (seeds of Thespesia populnea (L.; SOL.EX. CORREA), mercury, śivalingī bīja (seeds of Diplocyclos palmatus (L.; JAFFREY), rudrākșa (Elaeocarpus ganitrus ROXB.), sarpākși (Ophiorrhiza mungos L.), etc. drugs are used in these formulations. Three Garbhadhārana yōga (pro conception formulas) are mentioned. In these formulations darbhamūla (root of Imperata cylindrica (L.) RAEUSCH.), aśvagandha (Withania somnifera DUNAL), ikșvāku bijja (seeds of Lagenaria siceraria (MOLINA; STANDLEY), krūtamālabīja (seeds of Cassia fistula L.) etc. are used both internally as well as externally.

\subsection{Antenatal care}

Measures to be adopted during every month of pregnancy, preparations for easy delivery etc. are explained in detail. Candana (sandal wood), nīlōtpala (Nymphaea stellata WILLD.), mrnāla (fibrous roots of lotus), yașthi (Glycyrrhiza glabra L.), karpūra (camphor), pātalā (Stereospermum suaveolens DC.), mustā (Cyperus rotundus L.), kamkōlataìdula (Piper cubeba L. F.), cāgamāimsa (meat of goat), haridra (turmeric), hiranyaka (gold), padmaka (Prunus cerasoides D. DON), kuruvinda (Phaseolus radiatus L.), kaśēruka (Scirpus grossus L.F.), gajapippal̄̄ (Piper chaba HUNTER), priyamgu (Callicarpa macrophylla VAHL), madhuka (Madhuca indica GMEL.), sarasìruha (lotus) etc. drugs are used in various formulations. Among the foods Trnāadi pāyasa (sweet preparation with rice and jaggery), Pūpaka (biscuit/ cake like dish), Kŕśara (dish consisting of green gram and rice) etc. are mentioned during antenatal care. Śălmalī dhūpa is indicated for new-born child. Antenatal ailments are explained under the heading of garbhavēdana cikitsa. Karpūra (camphor), yașthi (Glycyrrhiza glabra L.), tilapișta (flour of sesame seeds), mrdvīka (grapes), utpala (Nymphaea stellata WILLD.), nīlottpala (blue variety of Nymphaea stellata WILLD.), puskala (Inula racemosa HOOK. F.), kèsara (saffron), pippalī (long pepper), vaca (Acorus calamus L.), kākōlī (Roscoea procera WALL.), śāliparṇ̄̄(Desmodium gangeticum (L.; DC.), varuñā mūla (root of Crataeva religiosa FORST.), madhuka (Madhuca indica GMEL.), padmaka (Prunus cerasoides D.DON), etc. drugs are used.

Mūẹhagarbha cikitsā (obstructed labour) is mentioned as a conversation between lord Śiva and Pārvati. Pippalìmūla (root of long pepper), parpamaka (Fumaria indica PUGSLEY), madhūkaphala (fruit of Madhuca indica GMEL.) etc. drugs are suggested to relieve obstructed labour. For sukhaprasava (eutocia) various internal drinks, external applications (pastes), knotting of medicated threads etc. are indicated. Mātulumiga (Citrus medica L.), guñjāmūla (root of Abrus precatorius L.) are two important drugs used for eutocia. 


\section{Gynaecological Disorders and their Treatment}

Palāśa (Butea monosperma (LAM.) TAUB), parpata (Fumaria indica PUGSLEY), śivalimin̄ (Diplocyclos palmatus (L.) JAFFREY) are used in puspa rahita strī cikits $\bar{a}$ (treatment for delayed menarche or primary amenorrhoea);

Under the heading of gynaecological disorders etiology, types and treatment of yōnipradara (menorrhagia) is mentioned. Vaginal tampon with mudgaparnittaila (oil extracted from the seeds of Phaseolus trilobus AIT.); medicated ghee prepared from madhuka (Glycyrrhiza glabra L.), padmaka bija (seeds of Prunus cerasoides D.DON), śatāvarī (Asparagus racemosus WILLD.), vidārī (Pueraria tuberosa (ROXB. EX. WILLD.), ikșumūla (root of sugar cane); mamjiṣtha (Rubia cordifolia L.), dhātaki puṣpa (flowers of Woodfordia fruticosa (L.; KURZ), nīlōtpala (blue variety of Nymphaea stellata WILLD.), lodhra (Symplocos racemosa ROXB.) and milk; Medicated milk prepared from aśōka valkala (bark of Saraca asoca (ROXB.) DE WILDE), rōhitamūlakalka (paste of root of Tecoma undulata G.DON) along with honey are indicated. Fruits and flowers of palāśa (Butea monosperma (LAM.) TAUB), kșīradrma (Ficus religiosa L.); śālmalī (Salmalia malabarica SCHOTT \& ENDL.) etc. are indicated in vandhyatvakarana (inducing sterility).

\section{Postpartum Care}

In nașta dugdha prasādana cikitsā (treatment for failure of lactation) internally kșīrānnabhōjana (rice cooked with milk) and ajjyamaimda (a type of soup) are indicated. Strīsaubhāgyavatīmōdaka, Strīyōgyavatīmōdaka and Sarvakaryasādhana gutikā are indicated for puerperal lady for regaining normalcy and alleviate puerperal diseases. Strīsaubhāgyavatīmōdaka contains mahaușadha (ginger), jātīphala (nutmeg), triphalā (three myrobalans), ajājīdvaya (two types of cumin i.e cumin and black cumin), dhānya (coriander), śatāhva (Anethum sowa KURZ.), èla (cardamom), upakulya (long pepper), drākșā (grapes), vidārī (Pueraria tuberosa (ROXB. EX. WILLD.), ghanasāraka (camphor) etc. drugs.

Strīyōgyavatīmōdaka contains babbūla (Acacia arabica SENSU BAKER variety vediana), gumdraka (Typha elephantina GRAH, NON ROXB.), aśvagandha (Withania somnifera DUNAL), mahaucadha (ginger), trikatu (three pungents), mēthikā (Trigonella foenum-graecum L.), śatapuspā (Anethum sowa KURZ.), lavaìgaka (cloves), jātīphala (nutmeg), jāpatri (mace), krșnajīraka (Carum carvi L.), dhānyaka (coriander), hapuṣa (Juniperus communis L.), vidaniga (Embelia ribes BURM.F.), tējavatī (Zanthoxylum armatum DC.), nāgapuṣpa (Mesua ferrea L.), punarnava (Boerhavia diffusa L.) etc. drugs.

Sarvakaryasādhana gutikā contains śrīkhañda (sandal wood), karikēsara (Mesua ferrea L.), gajamada (musth), gōrōcana (purified gall of cattle), padmaka (Prunus cerasoides D.DON), kumikumakēsara (stigmas of saffron), krṣna (black pepper), surataru (Cedrus deodara (ROXB.; LOUD.), sarsapa (mustard), uśîra (Vetiveria zizanioides (L.) NASH), krșṇatulasi (black variety of Ocimum sanctum L.), māmis $\bar{\imath}$ (Nardostachys jatamansi DC.), tvak (cinnamon bark), èla (cardamom), karpūra (camphor), tagara (Valeriana wallichii DC.), kāimcanāra (Bauhinia variegata L.), kētakīpuṣpāka (flower of Pandanus odoratissimus L.F.) etc. drugs.

\section{Classical Āyurvedic and other non CLASSICAL WORKS RELATED TO SUBJECT OF THE PRESENT MANUSCRIPT}

Many of the ingredients used in aphrodisiac medicines in various formulations of this text are also used for same purpose in ancient classics but the combinations and names of the formulations like Pañcaśaranāmarasa, 
Madanarasa, Madanakāmadēvarasa, Māṣa mōdaka, Māṣa vațaka, Gājaravidhi, Palāṇ̣u prayoga etc. are not available in ancient texts like Caraka samita and Suśruta samita. In classical Āyurvedic literature like Suśruta Samhita yōnisamivrtih word is used. As per Dalhana commentary yōnisamivrti is yōnisankōca (Susruta, 1996, p. 145). Stana katin̄̄karana yōga (drugs used to make breast firm and beautiful), Strīdrāvaṇām (female orgasm) and other factors enhancing sexual enjoyment were not directly mentioned in ancient classics. These things were given importance in contemporary texts on art of love like Vātsāyankāmas̄utra, Anamigaraìna, Ratirahasya, Kucimāratantra, Rahasya Śr̄̄ Dattātrēeyatantra, etc.

Vātsāyan kāmasūtra is a chief guide on Hindu erotic literature. In this text in part seven and chapter one, many recipes for increasing sexual vigour are explained and chapter two deals with medications and procedures to increase size of penis (Vatsayana. Kämasūtra, pp 224-238). Anangaranga of Kalyānamalla is a classic book on Hindu art of love. In this text in chapter six, eight internal medicines for increasing sexual vigour are explained (Kalyanamalla, 1977, pp.7677). In Kucimāratantra except gynaecological disorders and antenatal care remaining all the subject matter of the present text like aphrodisiac medicines, various vïiryasthambhana lèpa (anointments used for delaying ejaculation) and internal medications; yōn̄̄samikōcanayōga (formulations for vaginal narrowing), stana kaținīkaraṇa yōga (drugs used to make breast firm and beautiful), various beautifying drugs like depilators and hair enhancers, complexion promoting drugs, anti-lice drugs etc. are described (Prasad, 2007, pp. 1-50). Ratirahasya the 'secrets of Love' was written by a poet named Kokkoka. In the $15^{\text {th }}$ chapter of this text aphrodisiac medicines that enhance quality and quantity of semen is described (Kokkoka, 1994, pp.245-249). Rahasya Śrī Dattātrēyatantra is recently translated to Telugu language from the manuscript written in Sanskrit. Author and time of the text is unknown. This also contains aphrodisiac medicines, medicines for premature ejaculation and deals single child sterility, female orgasm and hair dyeing (Rao, 2016, pp. 67-96). These texts do not deal diseases of female

Treatment of various gynecological disorders is described in all major Ayurvedic classics like Caraka Samhitā, Suśruta Samhitā, Vāgbhata etc. Caraka Samhitā cikitsāsthāna $30^{\text {th }}$ chapter yōnivyāpaccikitsa, Suśruta Samhitā uttarasthāna $38^{\text {th }}$ chapter yōnivyāpatpratisêedhādhyāya are totally dedicated for gynecological disorders and their treatments. Antenatal care is mentioned in separate chapters in jātīsūtrīyam śārīram chapter of Caraka Samihitā (Agnivesa, 1992, pp 340-52; 634-50) and in garbhin̄ivyākaraṇam śārīra of Suśruta Samhitā (Suśruta,1996, pp 387-95; 668-70). As per the famous Āyurvedic professor of Prasütitantra and strīrōga (obstetrics and gynaecology), Premvati Tewari, classification of infertility has not been mentioned in any classics except Harìta Samhitā. Caraka and Vāgbhata have described vandhyatva (infertility) as an incurable condition of congenital absence of uterus and menstrual fluid (Tiwari, 2000, pp 283-85).

The beauty and uniqueness of the present text is to deal both art of love, enjoyment of sex, maintaining the beauty of woman, for her satisfaction maintaining the manly vigor of her partner and finally taken care of gynecological diseases, infertility and antenatal safety.

\section{Discussion and Conclusion}

$\bar{A} y u r v e d i c$ lexicons of ancient and medieval periods like Caraka, Suśruta, Vāgbhața, Mādhavanidāna, Bhāvaprakāśa, Yōgaratnākara, Cakradatta dealt all disciplines of medicine under one roof. At the end of medieval period, concept of specializations attained a new dimension and 
physicians of Āyurveda started dealing with specialities like Kaumārabrtya, Prasūtitantra, Strīrōga etc. Independent works, like Rāvaṇakrta Koumārabṛtya, Dēvēśvara Upādhyāya kṛta Strivilāsa are available. According to the Janet Chawla, the author of the book Birth and Birth givers: The power behind the shame, Strivilāsa is an independent book on the subject of obstetrics and gynaecology. This appears true, when we study this book. It is a unique manuscript with scope of lot of further research. Concept and naming of this text as Strìvilāsa is unique. Content of text accentuates that females' health and happiness depends also on her male partner's health. To make her sexual life happy, concentration on partner's health is also necessary.

In ancient times, the subject matter of obstetrics and gynaecology dealt under the speciality of Koumarabhritya, shows the Patriarchal ideology of Indian society. In contrast to that this book, perhaps the first book, considers the core needs of women and covered all the needs of women. Though it is dealt with medicines for delayed ejaculation, long-lasting penile erection etc., but in the point of providing pleasure to the female ultimately. Since ancient times, female orgasm is completely neglected and talking about the same is also abandoned as unwritten law. This work deals with female orgasm and the term given is Strìdrāvanām. In this view, this work is considered as revolutionary in its concepts.

Total text is written in a systematic way and the order of presentation is unique. First chapter starts with making female sexual life happy with usage of aphrodisiacs to her male partner, second chapter deals premature ejaculation / to sustain ejaculation for long time, third chapter deals vaginal canal narrowing, toning of vaginal muscles, making vagina free from foul smell (probably due to infections) and deals with conditions to promote orgasm in female. Fourth chapter concentrates on treatment of male sterility, and cosmetic preparations of hair, face, mouth etc.
Fifth chapter deals female sterility along with its types, sixth chapter is on treatment of female sterility, and antenatal care. Seventh chapter continues the treatment of female sterility and formulation to support normal labour, treatment of obstructed labour, postnatal care, and contraception.

In the beginning of history of India, aim of creating progeny was on the top order, this legacy continued till the medieval period. But in the modern times, after the population explosion, production of offspring is not alone the life motto, enjoying human life pleasures is realized. This book evidences that shifting paradigm of Indian society. It is a balanced text that has given equal importance to health of female, her sexual life, maintaining the beauty and ultimately aimed on good progeny.

Aphrodisiac medicines, aphrodisiac diets, medicines for delaying ejaculation etc. are to be studied further for validation. Concepts and role of medicines in lingamuśalīkaraṇa (to make penis hard like wooden pestle), yōnisankōcana (narrowing of lax vaginal canal/ making firm of vagina) and stana katinīkaraña yōga (recipes for shaping or hardening the breast), strìdrāvanām (female orgasm) are having scope for further study and their scientific validity. These concepts are well discussed in texts like Kucimāratantra, Anaìngaranga, Vātsāyanakāmasutra, Haramēkala etc. texts. Though very little research has been taken place to prove their validity on the above topics, lot of recipes in ancient texts in separate chapters denotes that there was frequent use of these medications and further minute level studies may reveal new facts. Medicines to make the male sterile, deodorant recipes, hair enhancers/ vitalizers, hair dyes, recipes to kill the lice, medicines those turn black hair to white, medicines used for alopecia, pimples, blackness in face; facial packs, and mouth fresheners are also unique and there is high scope for further validation. 
Female infertility types, their features and treatments, characteristic feature of various types of barren woman during or after coitus is also unique to this text. Though seven types of fruits and usage of seven herbs in chants are mentioned for the treatment of barren, their clinical efficacy should also be tried for validation. Treatment of one child infertility, history of stillbirth, pro conception formulas, antenatal care, treatment of obstructed labour, medicines for antenatal ailments, Eutocia, menarche, failure of lactation, menorrhagia etc. are having high scope for further research. In this text, excessive secretions (red or white) from vagina are denoted as yonipradara. Strī-saubhāgyavatīmōdaka, Strīyōgyavatīmōdaka,
Sarvakaryasādhana gutikā are special formulations for female with postnatal ailments.

Finally it can be concluded that this is a unique text having historical importance with lots of scope for further research in male and female infertility, gynaecological, obstetrical disorders and cosmetology.

\section{Acknowledgements}

The authors are highly thankful to Government Ayurvedic College, Gwalior for giving opportunity to digitize the manuscript and giving scope for studying the manuscript and present this article.

\section{APPENDIX}

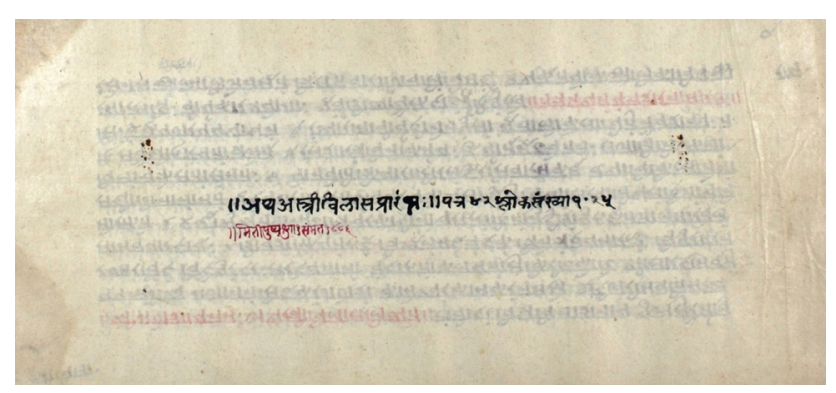

Cover page of Strīvilāsa, Ms. No 64 (Courtesy: Government Ayurvedic College, Gwalior)

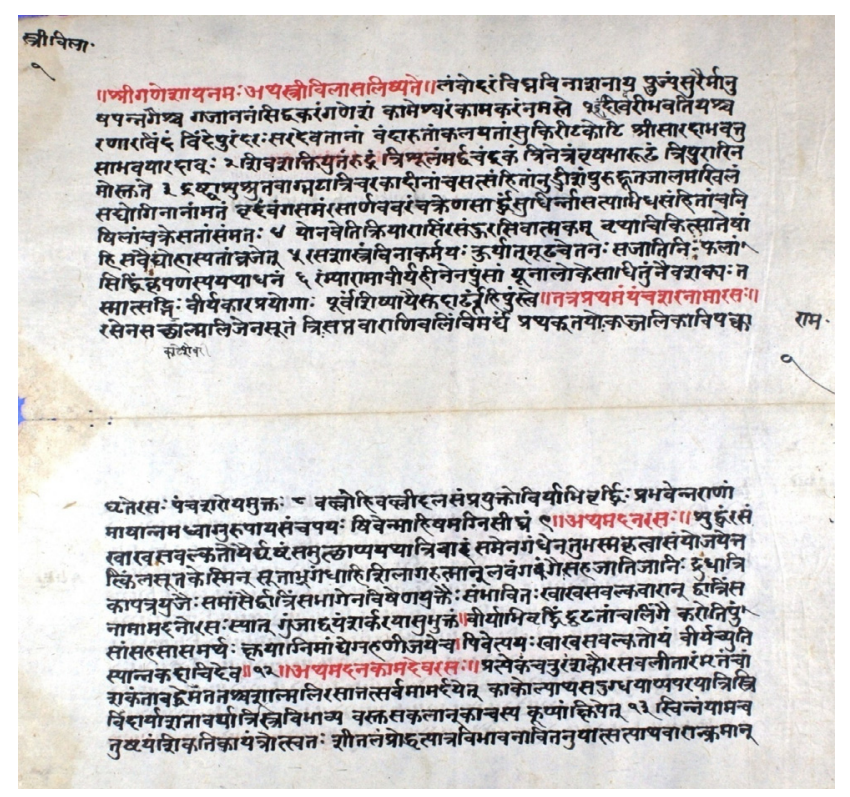

First page of Strīvilāsa, Ms. No 64 (Courtesy: Government Ayurvedic College, Gwalior 


\section{BIBLIOGRAPHY}

Caraka Samhita of Agnivesa with Dipika commentary of Cakrapani, edited by Vaidya Jadavji Trikamji Acharya, Chaukhambha Surbharati Prakashan, Varanasi, 1992

Chawla, Janet, Birth and Birthgivers: The Power Behind the Shame, Har Anand Publications, Delhi, 2006,

Kalyanamalla, Anangaranga, Sir Richard Burton translation, $1^{\text {st }}$ edition, Orient paperbacks publication, Delhi, 1977,

Kokkoka, Ratirahasya, edited and commented by Dr. Ramananda sharma, $1^{\text {st }}$ edition, Krishnadas Academy publications, Varanasi 1994

Krishnamachariar M. History of classical Sanskrit literature, Motilal Banarasidas publication, Delhi, 1989

Prasad, Goli Penchala (text with Eng. trans), Muni Kuchimara Kuchimara tantram, edited by Uttama Vaidya Pammi Satyanarayana Sastry, $1^{\text {st }}$ edition, published by Chowkhambha Krishna Das Academy, Varanasi, 2007
Rao, Lolla Ramachandra (Telugu Trans), Rahasya Dattatreya Tantram, (Anonymous), Mohan Publications, Rajamahendravaram, 2016.

Sharma, Priya Vrat, Priya Nighantuh, Chaukhambha Surbharati Prakashan, Varanasi, $2^{\text {nd }}$ edition, 1995

Sharma, Acharya Priya Vrat, Dravyagunakosh, Chaukhambha Orientalia publication, Delhi, $1^{\text {sT }}$ edition, 1997

Suśruta samhitā of Susruta, with Nibandhasangraha commentary of Sri Dalhanacharya, edited by Vaidya Jadavji Trikamji Acharya, Chaukhambha Orientalia publication, Varanasi, 1996.

Tiwari, Premvati, Ayurvediya Prasutitantra Evam Striroga, part II, Chaukhambha Orientalia, Varanasi, 2000

Vatsayana, Kämasutra, in pdf form. Pitbooks.com http:// www.pitbook.com/English/texts/pdf/kamasutra.pdf pp 224-238. 